\title{
Gizi Buruk dalam Perspektif Islam: Respon Teologis Terhadap Persoalan Gizi Buruk
}

\author{
Egi Sukma Baihaki \\ Sekolah Tinggi Filsafat Islam (STFI) Sadra Jakarta
}

\begin{abstract}
Nutrition is very important to the human body, as with nutrition that is quite capable of maintaining growth and health. The question of malnutrition was haunting the community each year. With the emergence of several cases of malnutrition, this paper seeks to explore and discuss how to respond to the issue of Islam and what are the solutions offered to address these problems. The method used is by examining Researh Library and browse through articles and studies related to the discussion in this paper. In the end it can be concluded that Islam pays attention to correct the quality of food that must be consumed in order for humans to avoid malnutrition. All parties should participate and take responsibility in tackling malnutrition. Solutions offered to tackle malnutrition, there are three aspects, namely the availability of food quality, social equity and community empowerment.
\end{abstract}

\begin{abstract}
Abstrak
Gizi sangatlah penting bagi tubuh manusia,karena dengan gizi yang cukup mampu menjaga pertumbuhan dan kesehatan. Persoalan gizi buruk selalu menghantui masyarakat setiap tahunnya. Dengan munculnya beberapa kasus gizi buruk, tulisan ini berupaya menggali dan membahas bagaimana Islam merespon persoalan tersebut dan apa saja solusi yang ditawarkan untuk mengatasi permasalahan tersebut. Metode yang digunakan adalah Library Researh dengan mengkaji dan menelusuri artikel dan kajian yang berkaitan dengan pembahasan dalam tulisan ini. Pada akhirnya dapat disimpulkan bahwa Islam memperhatikan betul kualitas makanan yang harus dikonsumsi agar manusia terhindar dari gizi buruk. Semua pihak harus turut serta dan bertanggung jawab dalam mengatasi gizi buruk. Solusi yang ditawarkan untuk mengatasi gizi buruk ada tiga aspek yaitu ketersediaan pangan berkualitas, pemerataan sosial dan pemberdayaan masyarakat.
\end{abstract}

Keywords: Malnutrition, Food, Equalizatio, Empowerment

\section{Corresponding author}

Email : egisukma_baihaki@yahoo.com 


\section{Pendahuluan}

Anak merupakan anugerah dan amanat dari Allah. Sebagai bagian dari keluarga, tanggung jawab orangtua terhadap anaknya berlaku semenjak anak berada dalam kandungan hingga ia memasuki usia tertentu. Sedangkan sebagai bagian masyarakat anak wajib memperoleh pelayanan dan perlindungan (Shihab, 2013, p.10).

Akan tetapi, berbagai masalah selalu menghinggapi anak-anak Indonesia khususnya yang berkaitan erat dengan kesehatan. Masalah kesehatan yang mengancam anak-anak Indonesia bukan hanya berdampak kepada fisik saja tapi juga tidak sedikit yang berakhir dengan kematian.

Salah satu masalah kesehatan yang mengancam anak-anak Indonesia adalah gizi buruk. Setiap tahun pemerintah terus menggenjot program untuk menurunkan angka gizi buruk agar tidak bertambah. Berbagai program baik itu pada aspek kesehatan, pendidikan dan ekonomi diadakan untuk mencegah terjadinya gizi buruk dari berbagai hulu. Meskipun Indonesia telah berusaha menekan angka peningkatan kasus gizi buruk, pada kenyataannya kasus gizi buruk tetap marak terjadi dan tidak turun secara drastis.

Kondisi ini tentu saja sangat memperihatinkan. Anak yang seharusnya menjadi generasi emas yang akan melanjutkan estafet kepemimpinan Negeri ini justru harus mengalami kondisi yang tidak layak. Padahal kondisi perekonomian dan pelayanan kesehatan telah ada, lalu faktor apa yang membuat kondisi tersebut terjadi secara signifikan. Bahkan dengan adanya upaya-upaya untuk menekan angka gizi buruk setiap tahun hanya mampu dilakukan perlahan dengan prosentase yang sedikit.

Di tahun 2017 ini saja sudah bermunculan kasus gizi buruk di beberapa daerah yang membuat cemas masyarakat hingga pemerintah. Padahal, kita baru saja memperingati Hari Gizi Nasional (HGN) yang ke-57, tetapi masih banyak masyarakat yang anggota keluarganya mengalami gizi buruk. Laporan Jawa Pos (Today, 2017) gizi buruk di Karawang selama tahun 2016 terdapat 257 kasus, laporan Tribun News, pada bulan Januari-Februari terdapat sembilan kasus gizi buruk di Nunukan (Ruru, 2017), laporan (Sukarelawati, n.d.), 22 balita di Malang terdeteksi gizi buruk (Antaranews Online), laporan (Maarif, 2017), terdapat 80 kasus gizi buruk di Pangandaran 49 berasal dari keluarga mampu dan 31 balita dari keluarga miskin (Maarif, 2017) dan masih banyak kasus lain yang terjadi beberapa bulan ini di tahun 2017.

Persoalan gizi buruk yang terjadi di Indonesia merupakan permasalahan yang begitu kompleks dan bersumber dari berbagai jalur. Oleh sebab itu, mengatasi permasalahan ini memang membutuhkan waktu yang lama juga perlu mendapatkan dukungan dari berbagai pihak. Islam sebagai agama yang menjunjung tinggi nilai-nilai kemanusiaan sangat menekankan pentingnya menjaga kesehatan dan makanan yang dikonsumsi oleh manusia sehari-hari. Oleh karena itu, permasalahan gizi buruk juga tidak lepas dari permasalahan yang dibicarakan dan dicarikan solusinya dalam kajian ke-Islaman.

\section{Pentingnya Gizi bagi Kehidupan}

Gizi sangatlah penting bagi kehidupan manusia mulai dari dalam kandungan hingga lanjut usia. Karena gizi tidak bisa dipisahkan sebagai elemen pendukung dalam kesehatan manusia. Gizi sangat penting untuk membantu pertumbuhan. Dengan gizi yang baik akan semakin meningkatkan kualitas hidup seseorang. Gizi yang baik juga berfungsi sebagai imun atau penangkal terhadap munculnya berbagai jenis penyakit. Makanan yang dikonsumsi oleh manusia harus dipertimbangkan kadar dan kualitas gizi yang ada di dalamnya sehingga dapat menjadi obat sekaligus imun bagi tubuh bukan menjadi sumber penyakit bagi tubuh.

Kandungan utama yang terkandung pada makanan adalah air, karbohidrat, protein, dan lemak. Makanan juga mengandung unsur penting lainnya seperti vitamin, mineral, antioksidan dan 
serat meskipun dalam jumlah yang kecil. Nilai gizi suatu makanan berkaitan erat dan bergantung pada komponen-komponen tersebut, dengan begitu akan memudahkan manusia untuk memilih makanan yang baik (Lajnah Pentashihan Mushaf Al-Qur'an dan LIPI, 2013, p.11).

Kandungan gizi dari makanan yang kita konsumsi sehari-hari akan sangat berpengaruh terhadap daya imunitas tubuh dan gerakan manusia. Selain itu gizi juga akan berpengaruh terhadap kesehatan manusia. Gizi yang baik akan memperlancar pertumbuhan dan daya kembang seseorang, sedangkan gizi buruk dapat berakibat berhentinya sebuah pertumbuhan. Contohnya dengan mengonsumsi buah-buahan, sayuran akan memperlancar pertumbuhan dan menyehatkan karena di dalamnya terkandung banyak vitamin. Jika kita malas atau kurang dalam mengonsumsi buahbuahan dan sayuran, tentu ada nilai gizi yang seharusnya terpenuhi dalam tubuh kita tapi tidak kita penuhi.

Dalam mengonsumsi sesuatu sudah selayaknya manusia bersifat lebih selektif. Jangan yang penting enak tapi tidak menyehatkan. Kesehatan pada dasarnya kembali pada diri kita sendiri, kalau kita tidak menyayangi tubuh kita berarti kita sendiri yang memang sudah merencanakan untuk segera mati.

Oleh sebab itu, kebutuhan asupan gizi yang cukup dan baik akan sangat berpengaruh terhadap pertumbuhan manusia dan juga kesehatan. Dengan demikian, persoalan gizi tidak dapat disepelekan dan dianggap sebagai sesuatu yang remeh, justru perlu diperhatikan dengan baik sehingga tubuh mendapatkan haknya yaitu mendapatkan asupan gizi yang baik dan cukup.

\section{Faktor Munculnya Gizi Buruk}

Kaitannya dengan pembahasan gizi, sebagaimana dijelaskan pada bab pendahuluan bahwa masih banyak masyarakat Indonesia yang mengalami kekurangan gizi. Hal tersebut disebabkan oleh beberapa faktor termasuk salah satu di antaranya adalah faktor makanan yang dikonsumsi. Permasalahan gizi memang sangat kompleks karena asupan gizi yang seharusnya masuk ke dalam tubuh manusia ada yang kurang dari standar, sehingga menyebabkan kekurangan gizi ada juga yang justru kelebihan. Karena bagaimana pun semuanya harus sesuai dengan standar yang ada. Jika berlebihan tentu ada implikasi yang ditimbulkan.

Menurut (Handayani, 2013, p.60) dilihat dari bahan-bahan pembentukannya, zat gizi dapat dikelompokkan menjadi dua bagian yaitu bahan organik (terdiri dari karbohidrat, lemak, protein dan vitamin), dan zat gizi yang bukan bahan organik (mineral dan air). Dari itu semua, ada tiga zat gizi yang dapat diubah menjadi energi yaitu karbohidrat, protein dan lemak, sedangkan vitamin mineral dan air diperlukan untuk membantu mengubah zat gizi tersebut menjadi energi. Pada umumnya bahan pangan, baik hewani maupun nabati mengandung zat gizi secara sempurna yaitu karbohidrat, protein, lemak, vitamin, mineral dan air. Proporsi zat gizi yang terkandung pada masing-masing jenis makanan tersebut, berbeda satu sama lain pada masing-masing jenis makanan. Sedangkan faktor yang dapat menyebabkan seorang anak kekurangan gizi antara lain; pertama, penyebab langsung yaitu makanan yang dikonsumsi anak dan penyakit infeksi yang mungkin diderita anak. Kedua, penyebab tidak langsung yaitu kondisi ketahanan pangan di keluarga, pola pengasuhan anak, kesehatan lingkungan dan pelayanan kesehatan.

Maka (Wirakusuma, 2010, p.231) menjelaskan bahwa tingkat kesehatan gizi bergantung pada tingkatan konsumsi yang akan berbuah kesehatan. Tingkat kesehatan gizi yang terbaik disebut kesehatan gizi optimal. Pada taraf ini, tubuh terbebas dari penyakit, memiliki daya tahan yang tinggi, dan memiliki daya kerja yang efesien. Konsumsi yang tidak seimbang (baik kurang ataupun lebih) akan menyebabkan gizi salah. Kekurangan gizi akan menyebabkan masalah yang disebut dengan gizi kurang.

Gizi buruk disebabkan oleh kurangnya asupan nutrisi dan gizi yang cukup untuk memenuhi 
kebutuhan tubuh manusia, sehingga menyebabkan tubuh manusia terhambat dalam proses pertumbuhan dan menimbulkan beberapa penyakit. Gizi buruk juga dikenal dengan sebutan malnutrisi.

Menurut (Jenggis, 2012, p.149) malnutrisi didefinisikan sebagai suatu kondisi seseorang yang menerima asupan gizi yang buruk. Karena itu, malnutrisi sering juga disebut juga sebagai gizi buruk. Malnutrisi disebabkan oleh kurangnya asupan makanan serta pemilihan jenis makanan yang tidak tepat ataupun karena sebab lainnya sehingga menyebabkan kurangnya asupan nutrisi dari makanan yang dikonsumsi.

Pola makan yang tidak teratur dan tidak sehat juga menjadi sumber malapetaka dari lahirnya gizi buruk. Tidak selektif dalam memilih makanan yang dikonsumsi sehari-hari, kurangnya pengetahuan terhadap nilai gizi dari suatu makanan akan berdampak kepada pola konsumsi yang tidak mempertimbangkan kepada kesehatan tubuh. Gizi buruk juga disebabkan oleh pola asupan gizi masyarakat dalam mengonsumsi makanan tanpa memiliki pengetahuan mengenai AKG (Angka Kecukupan Gizi) sehingga sembarangan dalam mengonsumsi suatu makanan.

Menurut (Handayani, 2013, pp.59-60) dalam menetapkan status gizi seseorang diperlukan pengukuran yang jelas untuk menilai apakah suatu masyarakat mengalami kekurangan gizi atau tidak. Angka Kecukupan Gizi (AKG) yang dianjurkan adalah suatu kecukupan rata-rata zat gizi yang dikonsumsi setiap harinya oleh seseorang disesuaikan dengan golongan, umur, jenis kelamin, ukuran tubuh, dan aktivitasnya. Dalam menghitung kecukupan gizi yang dianjurkan, biasanya sudah diperhitungkan faktor keberagaman terhadap kebutuhan masing-masing individu tersebut, sehingga, AKG merupakan nilai rata-rata yang dicapai masyarakat dengan indikator yang sudah ditetapkan sebelumnya.

Makanan yang bergizi membuat tubuh manusia menjadi kebal terhadap penyakit (Muslimin, 2011, p.245). Tapi, terdapat masyarakat yang salah dalam mempersepsikan dan memahami makanan yang disebut bergizi. Mereka berpikir bahwa makanan yang mahal adalah sumber gizi, padahal jika kita memahami teori ilmu gizi, makanan yang sederhana dan alami tanpa menggunakan bahan pengawet merupakan makanan yang mengandung banyak gizi.

Selain itu penghasilan yang rendah dan himpitan ekonomi juga dapat menjadi penyebab dari gizi buruk. Sebab himpitan ekonomi, kurangnya lapangan pekerjaan, mahalnya harga pangan membuat masyarakat tidak mampu mencukupi kebutuhan hidup sehari-hari dan memberikan makanan yang bergizi tinggi kepada anggota keluarganya. Gizi buruk merupakan akibat dari penghasilan yang rendah dan kurangnya pendidikan (President and Fellow of Harvad College, 2010, p.87).

Gizi buruk perlu diwaspadai bagi para ibu hamil. Memperhatikan asupan makanan yang bergizi selama kehamilan perlu untuk menghindari anak dari kekurangan gizi sejak di dalam kandungan. Nafkah lahiriah berupa pangan perlu diperhatikan dan dipenuhi dengan baik oleh seorang suami maupun seorang ibu. Sebab kurangnya asupan makanan bergizi saat di dalam kandungan juga dapat menjadi penyebab munculnya gizi buruk pada anak.

Menurut (Hanafi et al, 2008, p.121) jaminan perlindungan dalam bentuk nafkah sudah sesuai dengan ilmu kedokteran modern, gizi buruk bagi ibu hamil akan berdampak pada perkembangan janin khususnya pada trimeter pertama. Gizi buruk atau kekurangan gizi akan membuat kurang dan buruknya asupan makanan untuk janin. Kekurangan vitamin B kompleks misalnya, akan membuat janin memiliki beberapa masalah seperti kurang darah, kurus, serta lemah fisik dan mental.

\section{Pembahasan Islam tentang Makanan dan Kesehatan}

Islam sangat menekankan pentingnya manusia untuk memperhatikan kesehatan dan 
makanan yang dikonsumsi. Dalam beberapa literatur klasik Islam, akan dijumpai uraian-uraian yang menjelaskan pengobatan dan riwayat-riwayat mengenai kehidupan Nabi yang berkaitan dengan pengobatan dan makanan. Bahkan dalam sejarah peradaban Islam telah melahirkan para tokoh Tabib yang terkenal dengan maha karya mereka yang mengupas habis berbagai aspek kesehatan manusia. Oleh sebab itu, perhatian Islam terhadap kesehatan dan makanan yang dikonsumsi manusia menjadi pembahasan penting karena berhubungan erat dengan nilai-nilai kemanusiaan dan pendukung dalam beribadah.

Menurut Said Aqil Siroj perhatian Islam terhadap kesehatan masyarakat (public health) tampak pada ajaran-ajaran syariat Islam yang mengatur relasi sesama manusia. Dengan kata lain, pandangan Islam tentang kesehatan masyarakat berkaitan erat dengan konsepsi Islam tentang manusia sebagai makhluk sosial, yaitu manusia yang hidup dalam suatu komunitas atau masyarakat (Siroj, 2012, p.384).

Dalam kaitannya dengan kesehatan masyarakat dan kesejahteraan negara, gizi merupakan syarat untuk mencapai itu semua (Shihab, 2004, p.290). Sebab, tanpa kesehatan, manusia tidak dapat melakukan aktivitas. Sementara kesehatan dapat diperoleh melalui makanan yang bergizi. Menurut Shihab, hal itu menjadi jawaban mengapa Alquran, dalam banyak ayat yang mengaitkan aktivitas di bumi dengan makanan yang bergizi (misalnya QS 25: 20; 23: 5; 67: 15; 1: 60; 6: 142).

Menurut (Al-Farmawi, 2002, pp.160-167) terdapat 27 ayat yang berisikan perintah makan dan minum dalam berbagai konteks dan makna yaitu: QS. Al-Baqarah [2]: 57,58, 60, 168, 172, 187; QS.Al-Ma@idah [5]: 4, 88; QS.Al-An'a@m [6]: 118, 141, 142; QS.Al-A'ra@f [7]: 31, 160-161; QS.Al-Anfa@1 [8]: 69; QS. An-Nah\{1 [16]: 114; QS. T $\{\mathrm{a}>\mathrm{h}\{\mathrm{a}>$ [20]: 54, 81; QS. Al-H \{aj [22]: 28, 36; QS. Al-Mu'minu>n [23]: 51; QS. Saba [24]: 15; QS. Al-H \{a>qqah [69]: 24; QS. T\{u@r [52]: 19; QS. Al-Mulk [67]: 15; dan QS. Al-Mursala $>t$ [77]: 43, 46. Sedangkan yang relevan dengan pembahasan gizi adalah QS. Al-Baqarah [2]: 57, 168, 172, 267; QS. Al-Ma@idah [5]: 88, 96; QS. Al-An'a@m [6]: 141, 142; QS.Al-A'ra@f [7]: 31, 157, 170. QS.Al-Anfa@1 [8]: 69; QS.An-Nah\{1 [16]: 5, 14, 66-67, 69, 114; QS. T $\{\mathrm{a}>\mathrm{h}\{\mathrm{a}>$ [20]: 81; QS. Al-Mu'minu $>$ n [23]: 51; QS. 'Abasa []: 24-32.

Gizi mempunyai peran yang sangat besar dalam membina dan mempertahankan kesehatan seseorang (Shihab, 2004, p.286). Sudah menjadi sebuah kewajiban bagi setiap orang untuk memelihara kesehatannya, sebagaimana perintah yang disabdakan oleh Nabi Muhammad saw.: "Sesungguhnya badanmu mempunyai hak atas dirimu." Oleh sebab itu, sudah menjadi kewajiban bagi seseorang untuk memelihara jasmaninya, sehingga dapat berfungsi sebagaimana mestinya.

Menurut (Kurtubi, 2013, pp.60-61) pada dasarnya segala sesuatu yang ada di permukaan dan perut bumi, seluruhnya diperuntukkan untuk umat manusia, termasuk pada aspek makanan segalanya diperbolehkan untuk dikonsumsi, kecuali jika ada nash Alquran maupun hadis yang melarangnya. Pelarangan tersebut karena makanan tersebut bisa berakibat buruk atau tidak baik bagi diri manusia. Dalam ajaran Islam keterkaitannya dengan konteks mencari, memperoleh dan mengonsumsi makanan, manusia tidak bisa sembarangan dalam mengonsumsi makanan sesuai seleranya tanpa memperhatikan aturan-aturan dalam mencari, memperoleh dan mengonsumsi makanan. Makanan yang dibolehkan dalam Islam adalah makanan yang $h\{$ ala $>l$ dan baik ( $h\{$ ala@ lan t\{ayyiba). Dalam konteks keh\{ala>lan makanan sangat erat kaitannya dengan masalah hukum boleh tidaknya makanan itu dikonsumsi. Keh\{ala>lan makanan itu setidaknya dapat ditinjau dari dua segi, yaitu kandungan zatnya, dan cara memperolehnya.

Kata $h\{$ ala $>l$ dalam Alquran terdapat pada QS. Al-Baqarah (27): 168, QS. Al-Ma>idah (5): 80, QS. Yu>nus (10): 59, dan QS. An-N \{ahl (16): 114 dan 116. H\{ala>l didefinisikan sebagai sesuatu yang boleh dilakukan, atau boleh dimakan, dengan pengertian bahwa orang yang melakukan 
perbuatan tersebut tidak mendapat sanksi dari Allah. Biasanya istilah $h\{a l a>l$ berhubungan erat dengan makanan dan minuman (Al-Hafidz, 2006, p.93).

Alquran juga memberikan bimbingan dan petunjuk tentang pemenuhan kebutuhan manusia baik itu fisik maupun non-fisik (Muthi'ah, 2010, p.84). Para ulama bersepakat bahwa ajaran Islam sangat memperhatikan, bahkan bertujuan untuk memelihara segala aspek kebutuhan yang paling pokok bagi manusia, yaitu agama, jiwa raga, akal, kehormatan (keturunan), dan harta benda. Sebab upaya meningkatkan kualitas fisik manusia muslim melalui perbaikan gizi makanan, olahraga, dan pola hidup sehat atau cara lainnya, merupakan bagian dari upaya merealisasikan tujuan pokok syariat.

Dalam Alquran banyak disinggung persoalan makanan baik itu makanan yang dikonsumsi oleh kaum tertentu saja, makanan yang dikonsumsi kaum lainnya, makanan yang dilarang untuk suatu kaum, bahkan Alquran menghadirkan gambaran makanan yang kelak akan dikonsumsi oleh penduduk surga dan neraka. Alquran juga menitik beratkan persoalan kualitas makanan, sehingga sebuah makanan haruslah memenuuhi dua kriteria utama yaitu $h\{$ ala $>l$ dan baik (sehat dan layak konsumsi) Qs. al-N\{ahl: 114, Qs. al-Anfa>1: 69, Qs. al-Baqarah: 168 dan Qs. al-Ma>idah: 88. Dalam beberapa ayat lain term $h\{a l a>l$ dan t\{ayyib disatukan, dengan begitu penekanan kedua kriteria tersebut sangatlah penting untuk diperhatikan oleh manusia.

Menurut (Muthi'ah, 2010, pp.99-100) kualitas makanan dan minuman yang ditetapkan Alquran adalah $h\{a l a>l$ dan t\{ayyib. Dengan kuantitas yang proporsional, tidak berlebihan dan tidak kekurangan, serta memiliki pengaruh yang baik dan aman. Sedangkan jenis-jenis makanan yang dianjurkan adalah pangan nabati (seperti kurma, padi-padian, sayur-mayur, buah-buahan) dan pangan hewani (seperti daging hewan darat, ikan laut, susu, madu). Dengan petunjuk dan penjelasan Alquran, prinsip makanan bergizi "empat sehat lima sempurna" yang selama ini dikenal masyarakat dapat disempurnakan menjadi "lima sehat enam sempurna" yang mengakumulasi beberapa unsur seperti makanan pokok, sayur-mayur, lauk-pauk, buah-buahan, susu, madu, yang $h\{a l a>l$ dan t\{ayyib. H\{ala $>l$ adalah kualitas yang ditetapkan oleh syariat, sedangkan t\{ayyib di samping bersifat syariat juga secara ilmu gizi bersifat empirisional.

Terpenuhinya dua kriteria tersebut akan memberikan dampak positif tersendiri bagi kesehatan manusia. Dengan begitu manusia tidak akan sembarangan dalam mengonsumsi makanan atau minuman yang pada akhirnya dapat merusak kesehatan manusia sendiri. Oleh sebab itu, Allah memerintahkan manusia dalam Qs. Abasa: 24 untuk memperhatikan makanan yang dikonsumsi oleh manusia. Bukan hanya manusia biasa yang diharuskan untuk mengonsumsi makanan yang baik, para Rasul juga diperintahkan untuk memakan makanan yang baik (Qs. al-Mu'minu>n: 51).

Menurut (Tsabit, 2013, p.173) makanan yang sehat yang dianjurkan oleh Islam, tidak hanya terbatas pada persoalan $h\{a l a>l$ dan $h$ \{aram suatu makanan, tetapi juga menyangkut kualitas maupun kuantitas gizi dan porsi dari makanan tersebut. Dua hal itu sangat penting dalam kaitannya dengan kesehatan. Sebab kekurangan atau kelebihan zat gizi akan menyebabkan berbagai penyakit, dan berpengaruh terhadap kondisi ibadah seseorang.

Dalam kaitannya dengan makan dan minum, Alquran memberikan batasan-batasan seperti adanya klasifikasi $h\{a l a>l$ dan $h$ \{aram, sifatnya yang harus baik, hingga tidak boleh berlebihan dalam mengonsumsi makanan dan minuman (Qs. T $\{>\mathrm{a}>\mathrm{h}\{\mathrm{a}>$ : 81 dan Qs. al-A'ra>f: 31).

Menurut (Shihab, 2004, p.287) petunjuk lain yang ditemukan di dalam Alquran berkaitan dengan perintah makan adalah; Maka makanlah ia sebagai makanan yang sedap lagi baik akibatnya (QS 4:4). Ayat tersebut menunjukkan bahwa makanan yang dianjurkan adalah makanan yang sedap dan juga harus mempunyai akibat yang baik terhadap yang memakannya.

Memang makanan yang diciptakan oleh Allah SWT di bumi sangat bervariasi bentuknya, begitu juga dengan kadar gizi yang dikandungnya (Kurtubi, 2013 p.59). Banyak makanan yang 
sederhana bentuknya, tapi memiliki mutu dan gizi yang tinggi. Saat akan memilih makanan yang sehat dan bergizi tinggi jangan mudah terkecoh dengan bentuk atau kemasan yang bagus ternyata tidak memiliki kandungan gizi, apalagi sampai tidak memenuhi kriteria makanan yang $h\{a l a>l$ dan baik.

Menurut (Shihab, 2004, p.289) menarik pula untuk diperhatikan bahwa ketika Alquran berbicara tentang beberapa jenis makanan yang diharamkan, alasan pelarangannya karena ia adalah fisq (QS 5: 3; 6: 121; 6: 145). Kata tersebut walaupun pemakaiannya secara etimologis berarti "keluar" atau "melampaui batas", juga mengandung arti buah-buahan yang telah melewati batas kematangannya dan terkelupas kulitnya. Agaknya di sini pun dapat ditemukan isyarat atau kesan berkaitan dengan makanan yang teralu masak (matang) baik itu berupa buah-buahan maupun daging yang dalam kaitannya dengan ayat tersebut tidak dianjurkan untuk dikonsumsi.

Selain persoalan makanan yang di bahas di dalam Alquran, pembahasan mengenai air susu ibu (ASI) juga menjadi pembahasan penting karena asupan gizi bagi bayi pertama kali di dapatkan melalui air susu ibu (ASI). Bagi ibu hamil tanggung jawab terhadap anak bukan hanya menjaga kondisi tubuh agar tetap prima, tapi juga menjaga asupan yang dikonsumsi sehari-hari. Sebab hal itu akan berpengaruh terhadap kondisi bayi saat di dalam kandungan. Tanggung jawab seorang ibu juga berlanjut saat buah hati lahir, sebab seorang ibu harus menyusui anaknya. Air susu inilah yang pertama kali menjadi makanan bagi anak, sehingga untuk menghasilkan air susu yang baik seorang ibu juga perlu mengonsumsi makanan yang baik pula. Sebab gizi buruk juga disebabkan dari air susu ibu yang tidak memiliki nilai gizi yang baik.

Menurut (Shihab, 2004, p.287) secara khusus Alquran juga membahas makanan bagi bayi dan menjelaskan bahwa air susu ibu (ASI) merupakan makanan utama bayi. Oleh sebab itu, seorang ayah diperintahkan untuk memberikan imbalan kepada ibu yang menyusukan anaknya (QS 65: 6). Imbalan tersebut digunakan untuk menjaga kondisi kesehatan sang ibu dan kesempurnaan ASI yang dihasilkannya. Di lain sisi, Alquran mencela ibu yang tidak mau menyusui anaknya (QS 65: 6). Alquran menjelaskan bahwa masa penyusuan yang sempruna adalah selama dua tahun penuh (24 bulan) (QS 2: 233), atau 30 bulan dikurangi masa kehamilan (QS 46: 15).

Islam memercayai jenis susu sangat berdampak terhadap perkembangan anak (Amini, 2011, p.187). Oleh karena itu, Islam merekomendasikan umatnya untuk lebih cermat dalam memilih seorang istri. Pilihlah seorang wanita yang berakal, cantik, berakhlak baik, sehat dan kuat, supaya kelak melahirkan anak yang parasnya cantik, kuat, sehat, cerdas dan berakhlak baik. Islam juga menegaskan agar sebisa mungkin anak diberi air susu ibu. Jika terpaksa mengambil pengasuh atau ibu susuan untuk anak, pilihlah pengasuh yang berakal, cantik, berakhlak baik dan sehat, karena betapa pun juga air susu sangat berpengaruh terhadap perkembangan anak.

Menurut(Y. Hanafi, 2012, p.28) ASI memiliki banyak kandungan yang tidak didapatkan pada susu formula atau kemasan contohnya seperti zat immunologik. Pada ASI terdapat zat anti infeksi yang bersih dan bebas kontaminasi. Zat imun terdapat pada immunoglobin, sekretori, dan laktoferin . Belum lagi adanya faktor bifidus yang dapat merangsang lactobacillus bifidus untuk melindungi saluran pencernaan bayi. Sebaliknya, selain tidak ditemukan kandungan zat immunologik pada susu formula atau kemasan, justru pada susu formula atau kemasan terdapat kandungan bakteri yang dihasilkan akibat dari proses pengolahan dan pengemasan dan itu berbahaya bagi kesehatan bayi.

Makanan yang dikonsumsi seorang ibu langsung diserap oleh janin yang dikandungnya melalui tali pusar (Maftuhah, 2014, p.393). Proses itu diperlukan dalam pembentukan organ-organ embrio. Karena itulah, fase awal kehamilan sangat penting bagi perkembangan bayi yang akan lahir. Dalam kandungan semua proses pembentukan dimulai dari pembentukan otak, sumsum tulang belakang, sistem pencernaan, sistem kadiovaskular dan sistem yang ada dalam tubuh manusia. Oleh sebab itu, perhatian dan pilihan ibu dalam memilih makanan yang sehat, $h\{$ ala $>l$, baik, beragam dan 
bergizi sangat penting bagi terciptanya anak yang sehat jasmani, rohani, cerdas intelektual, pintar secara emosional dan beriman kepada Allah SWT.

Karena itulah, sudah menjadi tanggung jawab orang tua untuk memberikan asupan yang baik dan bergizi kepada anak-anak mulai sejak dalam kandungan hingga tumbuh dewasa. Anak adalah amanah yang perlu dijaga dengan baik dan akan dipertanggungjawabkan kelak di akhirat. Hal yang perlu diperhatikan bukan hanya akhlak, dan ibadah anak saja akan tetapi apa saja yang dikonsumsi oleh anak kita perlu diperhatikan nilai nutrisi dan gizinya sehingga anak kita akan terhindar dari penyakit. Beberapa hak anak atas orang tuanya menurut (Zaki, 2014, pp.7-8) antara lain, hak memperoleh ASI, dan hak anak dalam mendapatkan asuhan, perawatan dan pemeliharaan.

Menurut (Amini, 2011, pp.219-228) orang tua harus memperhatikan beberapa hal terkait dengan makanan dan kesehatan anak yaitu memperhatikan jenis makanan yang diberikan, jumlah makanan, makan secara teratur, tidak memaksakan anak makan, memelihara kesehatan dan mengobati anak (meliputi kebersihan, mencegah peyakit, dan mengobati anak).

\section{Solusi Terhadap Persoalan Gizi Buruk}

Dalam menghadapi persoalan gizi buruk yang setiap tahun selalu terjadi ada dua aspek yang dapat menjadi solusi terhadap permasalahan tersebut. Kedua aspek itu pun harus betul-betul diperhatikan bukan hanya oleh pemegang kebijakan dalam hal ini pemerintah pusat tapi juga pemerintah daerah, institusi kesehatan dan masyarakat Indonesia.

Menurut (Hernawati, 2017, pp.28-29) persoalan gizi buruk merupakan masalah kompleks, karena penyebabnya yang multi faktor dan multi dimensi. Penanganannya memerlukan pendekatan menyeluruh, meliputi penyembuhan dan pemulihan anak-anak yang sudah mengalami gizi buruk, serta pencegahan dan peningkatan dalam melindungi dan mempertahankan anak yang sehat agar tetap sehat. Kasus gizi buruk yang terjadi pada balita, merupakan fenomena gunung es yang menggambarkan keadaan gizi masyarakat seperti persoalan kesejahteraan masyarakat, yang meliputi daya beli, pendidikan dan perilaku kesehatan masyarakat meliputi lingkungan dan pemeliharaan kesehatan. Pencegahan dan penanggulangan gizi buruk tidak mungkin ditangani oleh salah satu sektor saja, dan tidak dapat dipecahkan melalui pendekatan kesehatan seperti penyembuhan dan pemulihan yang banyak dipersepsikan orang. Anak yang sudah pulih harus didukung secara terpadu dan dijaga agar tidak kembali mengalami gizi buruk. Karena itu, pencegahan dan penanggulangan gizi buruk memerlukan keterlibatan berbagai sektor yaitu dengan melakukan koordinasi antar sektor termasuk dengan masyarakat dan dunia usaha di setiap tingkat administratif dengan prinsip kemitraan.

\section{Pertama, Ketersedian Pangan Berkualitas}

Menurut (Rohaedi, Julia, \& Gunawan, 2014, p.86) gizi merupakan fondasi penting bagi kesehatan dan kesejahteraan sepanjang roda kehidupan. Berbagai faktor ikut memengaruhi dalam terciptanya sumber daya manusia yang bermutu, sehat, cerdas, dan produktif. Salah satu faktor yang sangat vital dalam mempengaruhi kondisi tersebut adalah tercukupinya kebutuhan pangan yang bergizi. Sebab ketahanan pangan merupakan salah satu permasalahan yang menjadi agenda pembahasan karena erat kaitannya dengan hak azasi manusia dan usaha pembangunan sumber daya manusia.

Karena itulah sebagai Negara yang dikenal sebagai lumbung padi, ketersediaan beras yang berkualitas sudah seharusnya dapat dinikmati seluruh elemen masyarakat. Jangan sampai masyarakat di pelosok kampung dan daerah kepulauan menikmati beras yang jauh dari standar yang ada. Ketersediaan bahan pangan dan kebutuhan pokok lainnya haruslah merata sehingga seluruh 
lapisan masyarakat dapat menikmatinya. Ketersediaan pasokan pangan dalam negeri harus selalu ditingkatkan kualitasnya, sehingga asupan gizi yang baik akan berpengaruh terhadap kesehatan masyarakat. Ketahanan pangan adalah garda depan bagi kehidupan masyarakat oleh sebab itu menjaga ketersediaan yang mencukupi dan akses memperoleh yang mudah sangatlah penting. Karena pangan adalah kebutuhan penting bagi masyarakat dalam menunjang kehidupan, bahkan aspek kesehatan pun bergantung pada persoalan pangan.

Menurut(Bank, 2008,p.135) di masa depan, pertanian akan terus memainkan peran sentralnya dalam mengatasi masalah ketahanan pangan. Pertanian dapat mempertahankan dan meningkatkan produksi pangan, serta memastikan ketersediaan pangan global. Pertanian juga bisa menjadi sarana utama untuk memberikan pendapatan bagi kaum miskin, dan mengamankan akses kaum miskin ke pangan. Melalui jenis tanaman pangan terbarukan yang unggul, pertanian dapat memperbaiki kualitasnya serta terjadinya keragaman pangan dengan begitu akan memperkuat hubungan antara ketahanan pangan dan ketahanan gizi.

Kondisi itu dapat terwujud jika didukung dengan kualitas distribusi yang mudah dan cepat. Distribusi yang baik dan lancar akan membuat harga pangan tetap stabil dan tidak melonjak sebagaimana harga yang mahal dirasakan di berbagai daerah kepulauan karena terlalu panjangnya alur distribusi, padahal dapat dipangkas. Dengan memangkas atau meminimalisasi jalur distribusi akan membuat permainan para tengkulak dapat dikurangi. Distribusi juga akan lancar jika insfratruktur atau jalur distribusi juga lancar. Pembangunan jalan-jalan khususnya di daerah pedalaman akan memudahkan akses masuknya kebutuhan masyarakat sehingga lebih mudah didapatkan. Kedua hal di atas saling berkaitan erat satu sama lain.

Dengan pemerataan distribusi ini akan membuat ketersediaan pangan di seluruh wilayah di Indonesia terpenuhi. Jangan sampai pasokan bahan pangan hanya berada di kota-kota besar, sehingga membuat daerah kepulauan atau perbatasan kesulitan mendapatkan bahan pangan termasuk dalam persoalan berbelanja.

Prinsip "belum makan, jika belum makan nasi" sepertinya memang betul adanya bagi masyarakat Indonesia. Akan tetapi, budaya tersebut sebetulnya di beberapa daerah telah berubah seiring dengan adanya masyarakat yang memanfaatkan bahan pangan lokal sebagai penggati beras seperti singkong, sagu dan jagung yang juga merupakan bagian dari bahan pangan berkarbohidrat layaknya beras. Perubahan budaya pangan masyarakat ini memang penting sehingga masyarakat memiliki alternatif lain sebagai makanan pokok dan tidak hanya mengandalkan persediaan dan pasokan beras. Di masa-masa sulit seperti banjir, paceklik, dan kekeringan, keberadaan makanan alternatif tersebut dapat menjadi solusi atas minimnya ketersediaan beras dalam Negeri.

Itulah mengapa menurut (Hanafie, 2010, p.1) budaya konsumsi pangan masyarakat salama ini terpaku pada aspek pemenuhan energi untuk melalukan aktivitas fisik. Adanya anggapan yang menganggap bahwa sumber pangan pokok yang mengandung karbohidrat hanya beras sangatlah keliru dan perlu diluruskan. Padahal masih banyak sumber karbohidrat selain beras dan dapat menggantikan posisi beras sebagai sumber energi pokok. Dengan demikian, saat negara tidak dapat menyediakan pasokan beras bagi masyarakat tidak dapat dianggap serta merta bahwa masyrakat kekuarangan pangan.

Erat kaitannya dengan upaya untuk memenuhi ketersedian pangan yang berkualitas dan mudah didapat oleh masyarakat dengan harga jual yang lebih terjangkau. Pemerintah harus selalu mengevaluasi ketersedian bahan pangan dan pendistribusiannya, dan mengawasi distribusi pangan hingga mencukupi kebutuhan pangan warganya. Pengawasan tersebut agar tidak terjadi penimbunan yang dapat berakibat kepada kelangkaan barang di pasaran dan melonjaknya harga. Dalam menginjak hari-hari besar keagamaan seperti Ramadan dan lebaran, sering kali terjadi kelangkaan dan naiknya harga-harga bahan pokok di pasaran. Pemerintah melalui kementerian dan instansi terkait juga perlu 
mengembangkan bahan pangan pengganti atau cadangan dengan bibit berkualitas. Kesejahteraan para petani juga perlu diperhatikan, mulai dari ketersediaan lahan, mudah memperoleh pupuk, bantuan alat pertanian, dan harga jual hasil pertanian. Jangan sampai harga beli dari petani lebih murah dan membuat petani merugi. Petani juga diharapkan mulai menanam pangan organik, serta pada proses tanam menggunakan pupuk organik dan mengurangi pemakaian bahan kimia. Produksi yang berkualitas, bermutu tinggi, dan ketersediaan yang mencukupi akan berdampak pada stabilitas harga bahan pangan dan menguntungkan para petani dan masyarakat.

\section{Kedua, Pemerataan Sosial dan Pemberdayaan Masyarakat}

Aspek kedua yang perlu disentuh dalam menghadapi persoalan gizi buruk adalah dengan memberdayakan masyarakat dan melakukan pemerataan sosial. Kedua hal tersebut adalah batu loncatan untuk mengikis kemiskinan yang dapat menyebabkan masyarakat tidak mampu untuk membeli dan mengonsumsi makanan yang bergizi.

Melalui makanan Allah memerintahkan kepada manusia agar manusia memiliki rasa kepekaan sosial terhadap masyarakat maupun lingkungan sekitar (Prasetiyo, 2016, p.129). Allah juga memerintahkan manusia untuk berbuat baik dengan memberikan sebagian makanannya kepada orang yang membutuhkan termasuk kerabat, tetangga, dan teman. Dalam hal ini Alquran memberikan penekanan berlebih kepada orang miskin dan anak yatim, karena dalam sebagian harta yang dimiliki seseorang di dalamnya terkandung hak orang miskin dan anak yatim.

Proses untuk meningkatkan kesehatan masyarakat salah satunya dapat dilakukan dengan meningkatkan kesejahteraan masyarakat dan memberdayakan mereka dari segi ekonomi baik itu persoalan lapangan pekerjaan maupun pangan. Dengan ketersediaan lapangan pekerjaan yang banyak akan memudahkan masyarakat untuk bekerja dan dari gaji yang cukuplah mereka dapat memenuhi kebutuhan mereka. Kesenjangan sosial dan ketimpangan yang terjadi di masyarakat perlu diperhatikan dan diatasi secara serius.

Menurut (Saputra \& Nurrizka, 2012, p.100) perlu strategi khusus dalam menangani persoalan gizi ini. Pertama, pendekatan kesejahteraan rumah tangga menjadi poin penting untuk mengatasi gizi kurang pada balita. Di mana risiko kemiskinan terhadap gizi kurang pada balita cukup besar. Perlu sentuhan terhadap program kemiskinan yang berkaitan langsung dengan peningkatan gizi balita terutama di kantong-kantong kemiskinan seperti nelayan, pertanian dan perkotaan. Program ini dapat melalui peningkatan pendapatan rumah tangga yang akhirnya berujung kepada perbaikan asupan gizi balita. Kedua, pelayanan kesehatan pada level posyandu perlu intensif dilakukan terutama pelayanan terhadap perbaikan gizi balita. Pemberian makanan tambahan pada balita merupakan hal terbaik untuk meningkatkan gizi balita. Ketiga, ditemukan lemahnya pengetahuan orang tua terhadap persoalan gizi ditemukan dalam studi ini. Untuk itu sosialisasi gizi perlu diintensifkan agar setiap keluarga dapat paham mengenai gizi tersebut. Keempat, program-program bantuan untuk masyarakat miskin perlu diintensifkan terutama melakukan versifikasi bantuan bukan saja terhadap karbohidrat tapi juga mencakup protein dan vitamin. Strategi ini akan efektif bila secara makro, perekonomian nasional dapat ditingkatkan dan kesejahteraan serta pendidikan masyarakat juga lebih dikembangkan sehingga angka balita gizi kurang di Indonesia menjadi lebih kecil.

Sedangkan menurut (Handayani, 2013, p.60) kita juga perlu memperhatikan beberapa hal yang akan berdampak kepada status gizi anak seperti pola pengasuhan anak baik dalam memberikan makanan, merawat, kebersihan dan kasih sayang yang diberikan kepada anak. Pelayanan dan akses kesehatan serta sarana pendukung kesehatan. Tidak terjangkaunya pelayanan kesehatan baik itu karena akses yang jauh ataupun karena kekurangan finansial, kurangnya pengetahuan menjadi kendala masyarakat dalam memanfaatkan pelayananan kesehatan yang tersedia. Ketidakterjangkauan pelayanan kesehatan (karena jauh dan tidak mampu membayar), kurangnya pendidikan dan 
pengetahuan merupakan kendala masyarakat dan keluarga memanfaatkan secara baik pelayanan kesehatan yang tersedia.

Pada dasarnya permasalahan gizi buruk adalah masalah yang menjadi tanggung jawab semua pihak. Pemerintah harus mampu menjamin kehidupan yang layak dan sejahtera untuk warganya sehingga distribusi pangan dan ekonomi masyarakat dapat tumbuh dengan baik dan akan berdampak pada kesejahteraan masyarakat sehingga mampu mencukupi kebutuhan sehari-hari secara layak.

Pengentasan kemiskinan merupakan salah satu solusi dari terjadinya kondisi rawan pangan, mengingat kemiskinan merupakan penyebab utama dari terjadinya rawan pangan. Kerawanan pangan dan gizi sangat memiliki hubungan yang erat dengan kualitas SDM (Purwantini, 2014, p.15). Dengan demikian, menurut (Aritonang \& Priharsiwi, 2006, p.21) upaya mengatasi gizi buruk sebaiknya bersifat 'memberi kail bukan ikan' yaitu dengan cara memberdayakan setiap keluarga dengan menyediakan lapangan kerja yang akan berimbas pada peningkatan daya beli.

Menurut (Siroj, 2012, pp.366-369) prinsip-prinsip yang harus diterapkan dalam lingkup hubungan sosial masyarakat khususnnya dalam kaitaannya dengan perekonomian adalah 1).Keadilan dalam distribusi kekayaan (al-'Adalah al-Itima'iyah) 2) Jaminan atas hak-hak dasar kemanusiaan (al-Kulliyah al-Khams) 3). Kesejahteraan Individu dan masyarakat (ar-rafahiyah al-fardiyah wa al-ijtima'iyah) 4) Persamaan derajat (al-Musawah) 5) Kebebasan (al-Huriyyah) 6) Moderasi (alTawassuth).

Berdasarkan kepada prinsip-prinsip tersebut, pemberdayaan masyarakat pada akhirnya adalah upaya berkelanjutan yang dapat mengikis persoalan gizi buruk dari dasar. Menyejahterakan kehidupan masyarakat Indonesia adalah bagian dari amanat yang dipegang oleh semua pihak.

Menurut (Departemen Agama RI, 1983, p.21) pada dasarnya usaha perbaikan gizi memiliki hubungan dengan rumusan tujuan hidup manusia menurut nilai-nilai Islam. Misalnya ajaran dan tatacara dalam memelihara kehidupan, memberikan arahan dan kriteria yang dibutuhkan untuk usaha perbaikan dan penyempurnaan gizi masyarakat. Karena itu, usaha memperbaiki kondisi gizi sebuah keluarga dan lingkungan masyarakat dalam ajaran Islam menjadi bagian yang tidak dapat dipisahkan dari amal dan bernilai ibadah juga menjadi bagian dari ibadah.

Banyak term tentang kemiskinan di dalam Alquran menunjukkan bahwa Islam memiliki perhatian yang lebih terhadap permasalahan tersebut (Zahro, 2011, pp.396-406). Islam memberikan beberapa solusi untuk mengatasi problem kemiskinan yaitu dengan zakat, infak, sedekah dan wakaf.

Pemberdayaan ekonomi yang menekankan pada sisi kesehatan sebetulnya dapat dilakukan dengan mengoptimalkan pengelolaan zakat, shadaqah, infak dan wakaf dengan membangun rumah sakit, memberikan bantuan dan fasilitas berobat gratis bagi fakir miskin atau juga bantuan biaya operasi bagi orang-orang yang membutuhkan.

Karena itu menurut (Shihab, 2003, pp.452-458) cara mengentasi kemiskinan adalah dengan mengoptimalkan beberapa kewajiban, seperti kewajiban setiap individu tercermin dari kewajiban bekerja dan berusaha, kewajiban orang lain atau masyarakat tercermin dengan jaminan satu rumpun keluarga, jaminan sosial dalam bentuk zakat dan sedekah wajib, dan kewajiban pemerintah dapat diwujudkan melalui pajak, baik pajak perorangan, tanah atau perdagangan dan pajak lainnya yang telah ditetapkan pemerintah bila sumber-sumber sebelumnya tidak mencukupi.

Jika keempat komponen tersebut dikelola dengan baik dan dapat dimanfaatkan oleh masyarakat maka secara perlahan problem kemiskinan dapat teratasi dan itu akan berdampak kepada peningkatan kualitas hidup masyarakat sehingga pola hidup sehat dan terpenuhinya gizi yang baik akan tercapai.

Dana yang terkumpul tersebut bukan hanya dapat digunakan untuk membangun beberapa fasilitas umum yang menunjang terhadap aspek pendidikan, sosial, dan agama seperti jalan, sekolah dan rumah sakit. Akan tetapi, dana tersebut juga dapat digunakan untuk dipinjamkan secara bergilir 
agar masyarakat dapat membuat program ekonomi kreatif sehingga dari dana tersebut masyarakat yang ingin membuka usaha dapat terbantu. Lembaga filantropi Islam melalui dana yang terkumpul dapat melakukan pelatihan wirausaha yang menyasar pada kaum muda, ibu-ibu muda, janda dan jompo serta memberikan fasilitas dan modal usaha sebagai bagian dari upaya pengentasan kemiskinan dan mencetak SDM berkualitas.

Pendistribusian dana tersebut jika merata dapat dinikmati oleh seluruh lapisan masyarakat. Keempat komponen penting itu memang selayaknya dikelola oleh satu lembaga sehingga dana yang terkumpul dapat berjumlah besar dan dibagikan keseluruh lapisan masyarakat yang membutuhkan.

Program-program pemberdayaan masyarakat yang mampu menyentuh lapisan terbawah dapat berdampak positif terhadap grafik penurunan angka gizi buruk di Indonesia. Jika ekonomi masyarakat sudah terjamin dan terciptanya kehidupan masyarakat yang sejahtera, maka asupan yang dikonsumsi oleh masyarakat Indonesia adalah makanan yang baik dan memiliki nilai gizi yang tinggi.

Selain itu ketersediaan akses berupa fasilitas pendukung kehidupan khususnya kesehatan seperti rumah sakit harus mampu menampung para warga miskin. Fasilitas kesehatan pada akhirnya bukan lagi dicap sebagai fasilitas yang hanya dapat dinikmati oleh orang kaya saja, akan tetapi dapat dinikmati seluruh lapisan masyarakat. Pembangunan posyandu, puskesmas dan rumah sakit di daerah perbatan atau kepulauan harus diperbanyak dengan didukung tenaga medis yang ahli dan mencukupi jumlahnya, juga dengan sarana kesehatan yang memadai.

\section{Kesimpulan}

Persoalan gizi erat kaitannya dengan ketersediaan pangan yang mencukupi. Selain itu, pendistribusian yang panjang terkadang membuat harga jual di beberapa wilayah berbeda-beda, sehingga banyak masyarakat khususnya yang tinggal di luar pulau atau pedalaman sulit untuk mendapatkan makanan karena jarak tempuh yang cukup jauh atau harga yang tidak terjangkau.

Gizi buruk dapat ditekan dengan pola hidup sehat yang harus diperhatikan oleh keluarga Indonesia. Mengetahui kandungan gizi dari makanan yang dikonsumsi akan berdampak langsung terhadap jumlah asupan gizi yang kita miliki. Islam menekankan makanan yang dikonsumsi oleh manusia harus memenuhi dua kriteria penting yaitu baik dan $h\{$ ala@l. Dengan begitu makanan yang kita konsumsi harus diseleksi sehingga dapat membantu pertumbuhan tubuh dan kesehatan.

Menjaga asupan makanan yang bergizi juga menjadi tanggung jawab bagi pasangan suami istri. Semenjak di dalam kandungan, seorang ibu harus menjaga kesehatan dan tumbuh kembang bayi dengan mengonsumsi makanan yang bergizi. Anak adalah amanat yang perlu dijaga dengan baik dan kita rawat dengan memenuhi segala kebutuhan hidupnya termasuk dalam persoalan asupan gizi.

Selain itu, persoalan gizi buruk dapat ditekan angkanya dengan memperhatikan ketiga aspek penting dalam kehidupan masyarakat yaitu ketersediaan pangan yang berkualitas, pemerataan sosial dan pemberdayaan masyarakat. Dengan tiga aspek ini diharapkan dapat meminimalisasi terjadinya gizi buruk dan mampu meningkatkan kesejahteraan hidup masyarakat Indonesia. 


\section{Referensi}

Al-Farmawi, A. H. (2002). Metode Tafsir Maudhu'i dan Cara Penerapannya. (R. Anwar, Ed.) (1st ed.). Bandung: Pustaka Setia.

Al-Hafidz, A. W. (2006). Kamus Ilmu Al-Qur'an. Jakarta: Amzah.

Amini, I. (2011). Asupan Ilahi 1. (A. Subandi \& S. Nano, Eds.). Jakarta: Al-Huda.

Aritonang, I., \& Priharsiwi, E. (2006). Busung Lapar. Yogyakarta: Media Pressindo.

Bank, T. W. (2008). Laporan Pembangunan Dunia 2008: Pertanian untuk Pembangunan.

(D. Sunardi, Ed.). Jakarta: Salemba Empat.

Departemen Agama RI. (1983). Pedoman Pelaksanaan Usaha Perbaikan Gizi Keluarga (UPGK) Melalui Jalur Kegiatan Agama Islam. Bekerjasama dengan UNICEF.

Hanafi, M. M., \& et al. (2008). Al-Qur'an dan Pemberdayaan Kaum Duafa. Jakarta: Lajnah Pentashihan Mushaf Al-Qur'an.

Hanafi, Y. (2012). Peningkatan Kecerdasan Anak Melalui Pemberian ASI dalam Al-Qur'an. Mutawâtir: Jurnal Keilmuan Tafsir Hadis, 2(1).

Hanafie, R. (2010). Penyediaan Pangan Yang Aman dan Berkelanjutan Guna Mendukung Tercapainya Ketahanan Pangan. JSEP (Journal of Social and Agricultural Ekonomics), 4(3).

Handayani, D. (2013). Strategi Perempuan dalam Kemandirian Gizi Keluarga (Studi Kelompok Pengajian Putri Nurul Hidayah Blabak Kota Kediri). MUWÂZÂH: Jurnal Kajian Gender, $5(1)$.

Hernawati, I. (2017). Pencegahan dan Penanggulangan Gizi Buruk Seminar Nasional Hari Pangan Sedunia XXVII. In Dukungan Teknologi Untuk Meningkatkan Produk Pangan Hewani dalam Rangka Pemenuhan Gizi Masyarakat. Badan Litbang Pertanian Departemen Pertanian.

Jenggis, P. A. (2012). 10 Isu Global di Dunia Islam. Yogyakarta: NFP Publishing.

Kurtubi, K. (2013). Keutamaan Mengonsumsi Makanan Halalan Tayyiba. Jurnal Edu_Bio: Jurnal Pendidikan Biologi, 4.

Lajnah Pentashihan Mushaf Al-Qur'an dan LIPI. (2013). Makanan dan Minuman dalam Prespektif Al-Qur'an dan Sains. Jakarta: Lajnah Pentashihan Mushaf Al-Qur'an.

Maarif, S. (2017). Balita Penderita Gizi Buruk dari Keluarga Mampu. Retrieved July 20, 2003, from https://daerah.sindonews.com/read/1184376/21/aneh-49-balita-penderita-gizi-buruk-darikeluarga-mampu-1488359514

Maftuhah. (2014). Makanan Halal dan Haram dalam Prespektif al-Qur'an, Sains, dan Kesehatan. Jurnal Bimas Islam, 7(2).

Muslimin. (2011). Pendidikan Agama Islam (1st ed.). Yogyakarta: Deepublish.

Muthi'ah, S. (2010). Gizi Menurut Al-Qur'an. Dalam Studi Al-Qur'an: Metode dan Konsep. (S. Syamsuddin, Ed.). Yogyakarta: eLSAQ Press.

Prasetiyo, J. R. (2016). Teologi Makanan Prespektif Al-Qur'an Kajian Tematik. UIN Sunan Kalijaga. President and Fellow of Harvad College. (2010). Indonesia Menentukan Nasib: Dari Reformasi ke Transformasi Kelembagaan. (P. Kompas, Ed.). Jakarta: Buku Kompas.

Purwantini, T. B. (2014). Pendekatan Rawan Pangan dan Gizi: Besaran, Karakteristik, dan Penyebabnya. Jurnal Forum Penelitian Agro Ekonomi, 32(1).

Rohaedi, S., Julia, M., \& Gunawan, I. M. A. (2014). Tingkat Ketahanan Pangan Rumah Tangga dengan Status Gizi Balita Di Daerah Rawan Pangan Kabupaten Indramayu. Jurnal Gizi Dan Dietetik Indonesia, 2(2).

Ruru, N. (2017). Sembilan Kasus Gizi Buruk di Nunukan Empat Orang Meninggal Dunia. Retrieved March 4, 2017, from http://www.tribunnews.com/regional/2017/03/03/sembilan-kasus-giziburuk-di-nunukan-empat-orang-meninggal-dunia 
Saputra, W., \& Nurrizka, R. H. (2012). Faktor Demografi dan Gizi Buruk dan Gizi Kurang. Makara Journal of Health Research, 16(2).

Shihab, M. Q. (2003). Wawasan Al-Qur'an: Tafsir Maudhu'i Atas Pelbagai Persoalan Umat. Bandung: Mizan.

Shihab, M. Q. (2004). Membumikan Al-Qur'an: Fungsi dan Peran Wahyu dalam Kehidupan Masyarakat. Bandung: Mizan.

Shihab, M. Q. (2013). Secercah Cahaya Ilahi: Hidup bersama Al-Qur'an. Bandung: Mizan.

Siroj, S. A. (2012). Tasawuf Sebagai Kritik Sosial: Mengedepankan Islam Sebagai Inspirasi, Bukan Aspirasi. Jakarta: SAS Foundation dan LTN PBNU.

Sukarelawati, E. (n.d.). Balita di Malang Terdeteksi Gizi Buruk. Retrieved March 30, 2017, from http://m.antaranews.com/berita/609452/22-balita-di-malang-terdeteksi-gizi-buruk

Today, J. (2017). Kasus Gizi Buruk Masih Tinggi terdapat 257 Kasus.

Tsabit, F. (2013). Makanan Sehat dalam al-Qur'an: Kajian Tafsir bi al- 'Ilm dengan Pendekatan Tematik. Yogyakarta: Pustaka Ilmu.

Wirakusuma, E. P. (2010). Sehat Cara Al-Qur'an dan Hadis. Jakarta: Hikmah.

Zahro, F. (2011). Islam dan Pengentasan Kemiskinan. (S. Syamsuddin, Ed.). Yogyakarta: eLSAQ Press.

Zaki, M. (2014). Perlindungan Anak dalam Perspektif Islam. ASAS: Jurnal Hukum Dan Ekonomi Islam, 6(2). 